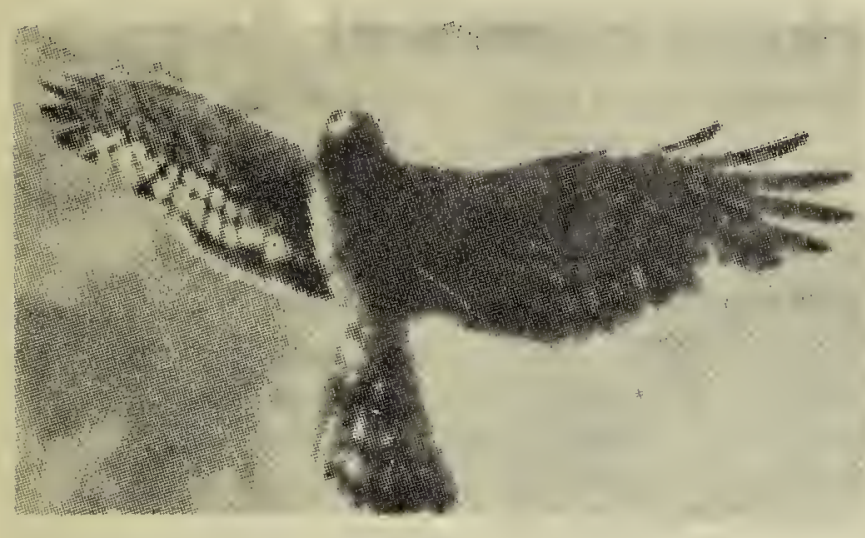

The true chicken hawks, the bluebacked, round-winged, long-tailed accipters such as the Cooper's and Sharp-shinned cause us little worry. We only see them in migration when we have no small chickens on the loose. They are hated by all smail birds and when one does turn up kingbirds, sparrows, blackbirds ali join in chasing them off. A few years ago we saw these birds during the summer and believed a few nested here. Now with a lot more of the land cleared we no longer see them except in migration.

The two Rough-legged hawks, and the larger falcons we see only in migration, and the Goshawk as a rare winter visitor.

Both the Bald and Golden eagle pay us sporadic visits, sometimes of but a few moments duration, at other times hanging around less habited parts of the district for weeks. Young of both the Bald and Golden eagles have come right into our yard at different times. A few years ago a young Golden eagle picked up a pullet but dropped ii when the men who were only a few yards away shouted. However, this boldness seems to go with youth and I've never seen an adult so close.

\section{Across Western Canada with the Birds in December}

\section{(Continued from page 5)}

to be Grosbeaks, doubtless from northern regions colder than they liked.

Where we came to rest in the northern part of the Okanagan Valley, a bright colored pheasant awakened us each dawn with his hoarse crowing and could be seen of a morning walking proudly through the pines and past the house, even in the city, built as it is, on hills and in hollows.

\section{BIRD SONG RECORDS}

\section{Harold Kreinge, Hawarden}

I wonder if our readers know about the Vinylite bird-song records sold by the T. A. Allen Company of Toronto. Volume 1 records 72 calls and songs of American birds, and Volume 2 records 50 calls of songs of birds. Many of the recordings are realistic and wonderfully natural. I have both of these volumes as well as a third which records the calls of 24 Eastern North American frogs and toads. It is splendid.

\section{A BOLT FROM THE BLUE}

\section{By Arthur Ward, Swift Current}

It was approaching dusk, and standing in front of one of the traps in order to let a banded bird free, there came a resounding thud against the back of the trap. Momentarily I was so taken aback that the hawk recovered and flew away. It had seen the bird (Harris Sparrow) in the trap and apparently had struck the trap feet first. Had it been head first it would have knocked itself out. It all happened so quickly that I could not identify it, but it looked like a Cooper's Hawk.

"I enjoy every article, and would not like to miss a single copy. I find Arch Budd's floral offerings most interesting, and love to walk with Elizabeth Cruickshank on her little tours and trips to the Valley."

-Mrs. Arthur Thompson, Rangor.

\section{APPRECIATION}

"I get an opportunity to see quite a few Society magazines but I believe the BLUE JAY is the most alive of any. Folks from the utmost places in the province have a finger in itand what a change from that mimeographed sheet!"

-P. H. Du Boulay, Montreal. 